up to date, but the section on heterocyclic compounds, including the chapter on alkaloids, must be amplified in a future edition if it is to satisfy the requirements of many of those students for whom the book has been written.

Le soleil. Par Prof. G. Bruhat. (Nouvelle Collection scientifique.) Pp. xii $+240+16$ planches. (Paris : Félix Alcan, 1931.) 20 francs.

PRof. BruHat has used a course of lectures given at the Sorbonne in 1930 as the basis of this book, but has eliminated to a great extent the mathematical treatment of his subject in order to reach a wider circle of readers. All who possess an elementary knowledge of physical sciences will find the book an interesting, clear, and up-to-date account of the present state of our knowledge of the sun, as well as of the instruments and methods used in attaining that knowledge. A considerable amount of this matter is not to be found in any English works of a similar nature, but the historical accounts are occasionally inadequate or even definitely misleading.

Problems concerning the internal constitution of the sun or its evolutionary history receive little or no attention, as being beyond the scope of the book ; apart from this, however, recent advances in observational methods, results, and theories form a prominent feature, and the whole supplies a good introduction to modern solar physics. The printing and paper leave much to be desired, and an index would have been a useful addition to the book. The plates are suitably chosen as representative of the subject matter and well reproduced; they are bound together at the end, and consist mainly of photographs taken at the Meudon Observatory.

A Manual of Determinative Mineralogy, with Tables : for the Determination of Minerals by means of 1. Their Physical Characters; 2. Blowpipe and Chemical Properties; 3. Optical Properties. By J. Volney Lewis. Fourth edition, revised by Prof. A. C. Hawkins. Pp. ix +230 . (New York : John Wiley and Sons, Inc. ; London: Chapman and Hall, Ltd., 1931.) 18s. net.

WITH the exception of certain minor alterations, the fourth edition of Prof. Lewis's well-known "Manual" differs but little from the third edition published in 1921. Prof. Hawkins, in his revision, has effected a very considerable saving in space, amounting to 68 pages, mainly in the physical tables. Instead of repetition in the case of such minerals as fall into two classes, an effective system of cross references has been employed. Further, in the tables of blowpipe reactions, certain rare and relatively unimportant species such as jarosite, glaucodot, etc., have been eliminated.

A short section has been added on optical properties, mainly with the object of impressing on the student the importance of optical properties in the determination of minerals. Optical data are given for a few common minerals. In its revised form, this work remains an exceedingly useful and simple guide to the determination of minerals according to their physical properties and blowpipe reactions.
Divorce : a Social Interpretation. By Prof. J. P. Lichtenberger. (Whittelsey House Publication.) Pp. xii + 472. (New York: McGraw-Hill Book Co., Inc.; London : McGraw-Hill Publishing Co., Ltd., 1931.) 21s. net.

THE use of scientific method and the disuse of appeals to authority, whether ecclesiastical or other, are the leading characteristics of this book. The author first states the problem, which is the explanation, not the justification, of the present divorce situation. He then enters upon a historical and descriptive account of marriage and divorce from the earliest to modern times, with special reference to America. Then, after considering some explanations of the divorce 'trend' which he regards as inadequate, he proceeds to develop his own lines of explanation. We think he begins badly by laying it down as an axiom that "divorce is an effect, not a cause", since the disintegration of the marriage has taken place before the divorce. But easy divorce is surely one cause of light views of marriage, and therefore of easy virtue. Yet there is so much excellent material in the book that it must be accounted a serious contribution. The author's wide knowledge of the literature of the subject makes him extremely apt in quotation.

\section{A Naturalist in Brazil: the Flora and Fauna and} the People of Brazil. By Prof. K. Guenther. Translated by Bernard Miall. Pp. $400+32$ plates. (London: George Allen and Unwin, Ltd., 1931.) 25s. net.

THus is an admirably illustrated book on the flora and fauna of Brazil. It marshals the natural history of the country in an instructive manner, but we do not discover that the author has concentrated on any special problem or added much to our previous knowledge. His chapters on "The Mosaic of Colours" and "The Symphony of Voices" are attractive, while the variety of devices em. ployed by parents for ensuring the survival of their young will attract many readers. This is a book invaluable to anyone who desires to visualise the country and its inhabitants, a pleasant 'Baedeker' of Nature.

The Sciences of Man in the Making : an Orientation Book. By Edwin A. Kirkpatrick. (International Library of Psychology, Philosophy and Scientific Method.) Pp. xv + 396. (London: Kegan Paul and Co., Ltd., 1932.) 15s. net.

Is the short compass of this volume, the author surveys the various sciences referring to man, from anthropology and ethnology to economics and politics, and from psychology to morals. No particular views are expressed, which belongs to the 'orientation' type now so popular in the United States. The 'suggested readings' at the end of each chapter refer almost entirely to American publications and authors. As a restatement of questions of methods relating to the study of mankind, however, the book makes enjoyable reading. 